\title{
SIGNIFICADO DE SUCESSO PROFISSIONAL SOB A ÓTICA DOS ALUNOS DO ENSINO MÉDIO
}

\section{ARTIGO ORIGINAL}

GUIDA, Simone Leite Azevedo Gurgel ${ }^{1}$

SOUZA, Marilza Terezinha Soares de ${ }^{2}$

GUIDA, Simone Leite Azevedo Gurgel. SOUZA, Marilza Terezinha Soares de. Significado de sucesso profissional sob a ótica dos alunos do Ensino Médio. Revista Científica Multidisciplinar Núcleo do Conhecimento. Ano 05, Ed. 04, Vol. 06, pp. 91-112. Abril de 2020. ISSN: 2448-0959, Link de acesso: https://www.nucleodoconhecimento.com.br/educacao/sucesso-profissional

\section{RESUMO}

O objetivo deste estudo é compreender o significado de sucesso profissional para alunos do primeiro ano do ensino médio, de uma escola pública, na região do Vale do Paraíba. Trata-se de uma pesquisa exploratória, com abordagem qualitativa. Os dados foram coletados por meio da realização de grupo focal, com dezessete estudantes do Ensino Médio. Para análise, foi utilizada a Teoria Fundamentada nos Dados. Os resultados revelaram três categorias emergentes: Variáveis na forma de conceber o sucesso profissional, Possíveis condições ou não para obtenção de sucesso profissional, Elaboração estratégica para obtenção do sucesso profissional, que descrevem crenças, valores e influências socioculturais dos estudantes em relação ao significado de sucesso profissional.

Palavras-chave: Estudante, Ensino médio, sucesso profissional.

\footnotetext{
${ }^{1}$ Mestranda em Educação, Especialista Em Docência do Ensino Médio, Técnico e Superior em Enfermagem, Graduada em Enfermagem.

2 Doutora em Psicologia.
} 


\section{INTRODUÇÃO}

É comum que o sucesso profissional, almejado pelo jovem contemporâneo, contemple o processo de escolha profissional e sua inserção no mercado de trabalho. A escolha da profissão é um fator motivacional de crescimento para os jovens, imprimindo sentido em sua trajetória pela busca de sucesso na carreira, o que torna o tema relevante.

Transformações socioeconômicas ocorridas na contemporaneidade propiciam ao jovem uma visão diversificada na forma em conceber o sucesso profissional, desmistificando a ideia de estabilidade financeira, como forma de ser bem sucedido, promovendo uma versatilidade nesta concepção, na qual o sucesso não acontece somente vinculado a satisfação financeira, mas por meio da satisfação pessoal, desta forma o problema de pesquisa é identificar a forma como o jovem compreende e significa o sucesso profissional conforme seu contexto socioeconômico perante suas crenças e valores.

\section{SIGNIFICADO DE SUCESSO PROFISSIONAL E SUAS DIMENSÕES}

A busca de uma definição para o significado de sucesso pode remeter o sujeito a uma vasta conceituação, pois não há clareza ou facilidade na sua compreensão. O termo sucesso converge a uma diversidade de significações, que são baseadas em seus diversos conceitos, os quais, segundo Maia (2000), tornam-se uma hegemônica uniformidade e remetem à ideia de vitória. Assim, essa vertente do sucesso está em consonância com a ideia de positividade.

Todavia, em uma sociedade marcada por desigualdades, o sucesso pode ser concebido sob diferentes aspectos pelos jovens, não estando apenas vinculado a aspectos positivos. A condição de frequentar a escola pública, por exemplo, muitas vezes é vista como um dificultador para o ingresso na faculdade, em função da deficiência da formação dada aos alunos, dificultando seu acesso ao nível superior e, consequentemente, o atingimento do sucesso (Souza et. al, 2007). 
Quanto à definição do conceito de sucesso, Maia $(2000$, p.8) afirma que:

O sucesso é um conceito do nosso cotidiano. Com dimensões que se estruturam entre o conseguir "ter" até ao conseguir "ser", os significados que Ihe atribuímos estão ligados à ideia de ser capaz, de conseguir, de vencer, de alcançar.

A ideia de sucesso apresenta-se sob um conceito socialmente relevante e sua variação tem sua relevância à medida em que se analisa o formato que as representações das pessoas ocorrem dentro do grupo ao qual pertence. Essas representações ocorrem por meio da evolução das pessoas em uma mobilidade social, pois o indivíduo vivencia uma expectativa que pode ir além do contexto em que vive, vincula-a à vontade de vencer e acaba por não se limitar ao conformismo (Maia \& Poeschl,2004).

Os autores supracitados identificam várias dimensões de sucesso, dando destaque a seis dimensões. A primeira dimensão, centrada no esforço, identifica o trabalho como árduo, que exige dedicação, aptidões físicas, treino e prática, como componentes essenciais para alcançar o sucesso. A segunda dimensão, de natureza intelectual, está além do esforço físico, conectando-se à capacidade psicológica. Essa dimensão, voltada à capacidade psicológica, associa-se a aspectos da criatividade, do empreendedorismo e da inteligência, os quais constituem componentes para perpetuar o sucesso. Embora divergentes, nota-se que o trabalho é o elo entre a primeira e segunda dimensões das representações de sucesso.

$\mathrm{Na}$ terceira dimensão, a autoconfiança relaciona sucesso à auto capacidade de iniciativa, eficácia, capacidade de decisão, força de vontade, persistência, pensamento positivo ao lidar com derrotas e autoestima. A quarta dimensão é a socio relacional, ou seja, a que considera a forma de socialização entre as pessoas. Nessa dimensão, observa-se que possíveis dificuldades de comunicação ocorrem devido à falta de simpatia, gentileza e ponderação, as quais são características importantes a serem praticadas. Notavelmente, a terceira e a quarta dimensão estão inter- 
relacionadas, já que vinculam a autoconfiança às relações humanas e de comunicação.

Maia e Poeschl (2004) concluem as dimensões de sucesso com significado espiritual e de equilíbrio do corpo. Nessa perspectiva, a quinta dimensão denota o sentido de sucesso para um espaço de fé e desejo de Deus, trazendo contentamento interior. Já a sexta dimensão relaciona a saúde ao sucesso, de forma que compreende o equilíbrio do corpo, por meio da sua funcionalidade pela ingesta de alimentos, pois o alimento influencia o bom funcionamento do organismo tanto a nível físico como mental. Nesse caso, a ausência de boa saúde dificulta a obtenção de sucesso.

Todas essas dimensões de sucesso, embora tenham sido apresentadas separadamente, mantêm uma mútua interação, como afirma Maia (2000, p. 23): "Este "elixir", fórmula mágica, assentará numa combinação de todos estes múltiplos "ingredientes", para alcançar um "estado de sucesso"."

Sob a ótica da subjetividade, o sucesso está voltado à satisfação interior, mais do que aos resultados percebidos externamente na carreira escolhida, como dinheiro, título ou posição social. Na contemporaneidade, esse parece ser o viés do sucesso, pois o jovem busca um trabalho que proporcione, mais do que subsistência, um sentido de autorrealização (Venelli-Costa; Rodrigues; Kilimnik \& Mesquita, 2017).A opção por uma carreira, faz parte do desenvolvimento do jovem, de forma que sua escolha 0 conduza a sua meta e promova sua satisfação pessoal (Junqueira, 2010).

Nos estudos de Oliveira, Detomini e Silva (2013), o sucesso foi vinculado à realização de algo bom e positivo, relacionando-se à posição social e à riqueza. Esses autores, embora apontem para um consenso aparente na definição do termo, não desprezam a amplitude que ele incorpora, pois, a percepção de sucesso é variável, imprimindo ao conceito um significado subjetivo. Nessa compilação de ingredientes para obtenção de sucesso, o jovem é confrontado com a necessidade de realizar escolhas e planejar seu futuro. 


\section{ESCOLHA PROFISSIONAL}

A escolha profissional é um momento decisivo na vida do jovem, envolvendo aspectos voltados à definição da carreira, o que é determinante na trajetória que o conduzirá na futura profissão (Noronha \& Otatti, 2010).Como essa escolha profissional geralmente ocorre durante o Ensino Médio, isso gera expectativas em relação ao futuro e acaba levando a uma opção permeada por influências externas. Nesse momento da escolha profissional, o jovem confronta-se com suas condições socioeconômicas e culturais, as quais exercem influências sobre suas decisões. (Santana, 2017).

No que tange às questões econômicas que são decisivas, pode-se afirmar que a trajetória para alcançar o objetivo almejado em relação à profissão pretendida pode ter seu início com obstáculos a serem superados pelo jovem. Dentre eles estão: a falta de proventos para pagar um curso pré-vestibular ou mesmo sua realidade social que o conduza ao mundo do trabalho (Bastos, 2005). Essa mesma autora retrata um contexto controverso na escolha profissional. Ao mesmo tempo em que o Ensino Médio teve um aumento na sua oferta, possibilitando maiores oportunidades tanto para o mundo do trabalho quanto para a ideia de cursar a universidade, por outro lado as questões socioeconômicas posicionam-se como limitadores desse objetivo. Embora não determinem em definitivo suas escolhas, essas questões podem inibir horizontes do jovem, reduzindo suas opções para o ingresso na faculdade ou no mercado de trabalho.

A respeito dessas interferências na escolha profissional bem como dos aspectos individuais que a circundam, Santana (2017, p.57), identifica que:

Para os jovens do Ensino Médio de escolas públicas, o momento de decidir por caminhos a seguir é também a possibilidade de inserção profissional. A escolha determina e é determinada pelas possibilidades presentes que irão impactar no futuro. É uma escolha que não se dá de forma neutra; pois é permeada pelo mundo objetivo (o que proporciona) e pelo mundo subjetivo (o que representa para o jovem estudante). 
Conforme se percebe, a escolha nem sempre ocorre sem a dúvida, é um momento de opção, um caminho a decidir entre outras possibilidades, por isso conflitos podem ocorrer. Entretanto, é um processo de evolução no percurso da vida (Santana, 2017).

Alterações sociais, que ocorreram na década de 1990, ocasionaram mudanças na concepção da escolha profissional, a qual deixou de ser baseada em conceitos tradicionais, como renda fixa, estabilidade no trabalho, e passou a ser vista como algo relacionado à flexibilidade, estratégias e mobilidades em projetos com menor intervalo de tempo (Buscacio \& Soares, 2017). A partir desse novo cenário relativo à escolha da profissão, o jovem confronta-se com um percurso diversificado para obter sucesso profissional, nesse sentido a subjetividade do sujeito emerge a partir de valores como: satisfação, habilidade, equilíbrio entre família e trabalho, dando uma significação pessoal à percepção de sucesso. Portanto, conforme estas considerações, a pesquisa busca compreender qual significado o jovem de ensino médio atribui ao sucesso profissional, por meio de suas crenças, valores e influências socioculturais.

\section{MÉTODO}

A opção pelo método qualitativo para esse estudo ocorreu por contemplar a investigação dos significados, crenças e valores, pois, ao contrário da pesquisa quantitativa, em que se utilizam dados estatísticos, proporciona um estudo da exploração e do subjetivismo (Minayo, 2002).

Para realização dessa pesquisa, foram convidados a participar as três séries do ensino médio, selecionados dezessete alunos de ambos os sexos. Foi realizado um grupo focal por série, e este estudo apresenta os resultados referentes ao primeiro ano do ensino médio com a participação de três alunos. A pesquisa foi submetida ao Comitê de Ética em Pesquisa com Seres Humanos da Universidade de Taubaté (CEPUNITAU) sob número do parecer: 3.092.479 e obteve sua aprovação.

O instrumento para a coleta de dados utilizado nesta pesquisa foi grupo focal, que de acordo com Bonfim (2009), é um modo de entrevista em grupo, por meio da interação entre as pessoas. Conforme o objetivo da investigação, os critérios foram 
determinados pelo pesquisador. Todas as informações obtidas refletem as percepções, crenças e atitudes dos indivíduos. Por meio da realização do grupo focal para coleta de dados, com os alunos dos primeiros anos, os diálogos foram gravados em áudio, transcritos e copiados para software The-Ethnograph 6.0 Qualis Research e posteriormente analisados.

A análise dos dados coletados foi realizada a partir da Teoria Fundamentada nos Dados (TFD), conforme Strauss e Corbin (2008), essa teoria é derivada dos dados, reunidos e analisados por meio de pesquisa. Os mesmos autores afirmam que a teoria proveniente dos dados se aproxima melhor da realidade do que a teoria baseada na reunião de uma sequência de conceitos definidos por experiências ou provenientes de investigação.

Os dados foram analisados por meio da TFD, que é uma teoria criativa, segundo Strauss e Corbin (2008). Permitiu uma análise detalhada e comparativa dos dados, englobando as etapas a seguir:

- Codificação aberta: essa fase compreendeu a interação dos dados com o pesquisador, momento para exposição do texto, de ideias e significados, foi nomeado e identificado os conceitos que representam o que os dados transmitiram. Nessa etapa, ocorreu a inspeção e comparação dos dados na busca de semelhanças e diferenças. Quando identificadas tais similaridades e diferenças, foi realizado o agrupamento dos conceitos. Nessa codificação aberta, por meio da microanálise o texto foi examinado linha por linha, e recortado a unidade de análise, que foi nomeada com uma palavra ou sentença, expressando o significado para o pesquisador. Esse mesmo procedimento foi utilizado para analisar uma frase, uma palavra ou um parágrafo. Nesta fase, foi utilizado os memorandos, que atuaram como lembretes ou fontes de informação, foram anotações feitas para armazenar ideias, de forma analítica e reflexiva, auxiliaram na integração dos conceitos no decorrer da análise dos dados.

- Categorização: essa fase permitiu ao pesquisador agrupar conceitos semelhantes em categorias, de forma a dar significado ao que estava 
acontecendo. Este agrupamento permitiu a redução do número de unidades com as quais o analista trabalhou, estas categorias são conceitos que representam um fenômeno.

- Codificação axial: nessa fase foi realizada a verificação de como as categorias e subcategorias se associaram, pois, elas se relacionam entre si de modo a originar explicações evidentes e precisas sobre o fenômeno.

- Fenômeno central ou codificação seletiva: é a fase em que ocorreu alinhamento e interação das categorias, representando o tema central da pesquisa e reunindo outras categorias, de forma a obter um formato explicativo.

Para auxiliar na compreensão do percurso adotado, a Figura 1 ilustra o tratamento e a forma analítica na obtenção dos dados, com base na TFD.

Figura 1 - Tratamento e a forma analítica na obtenção dos dados.

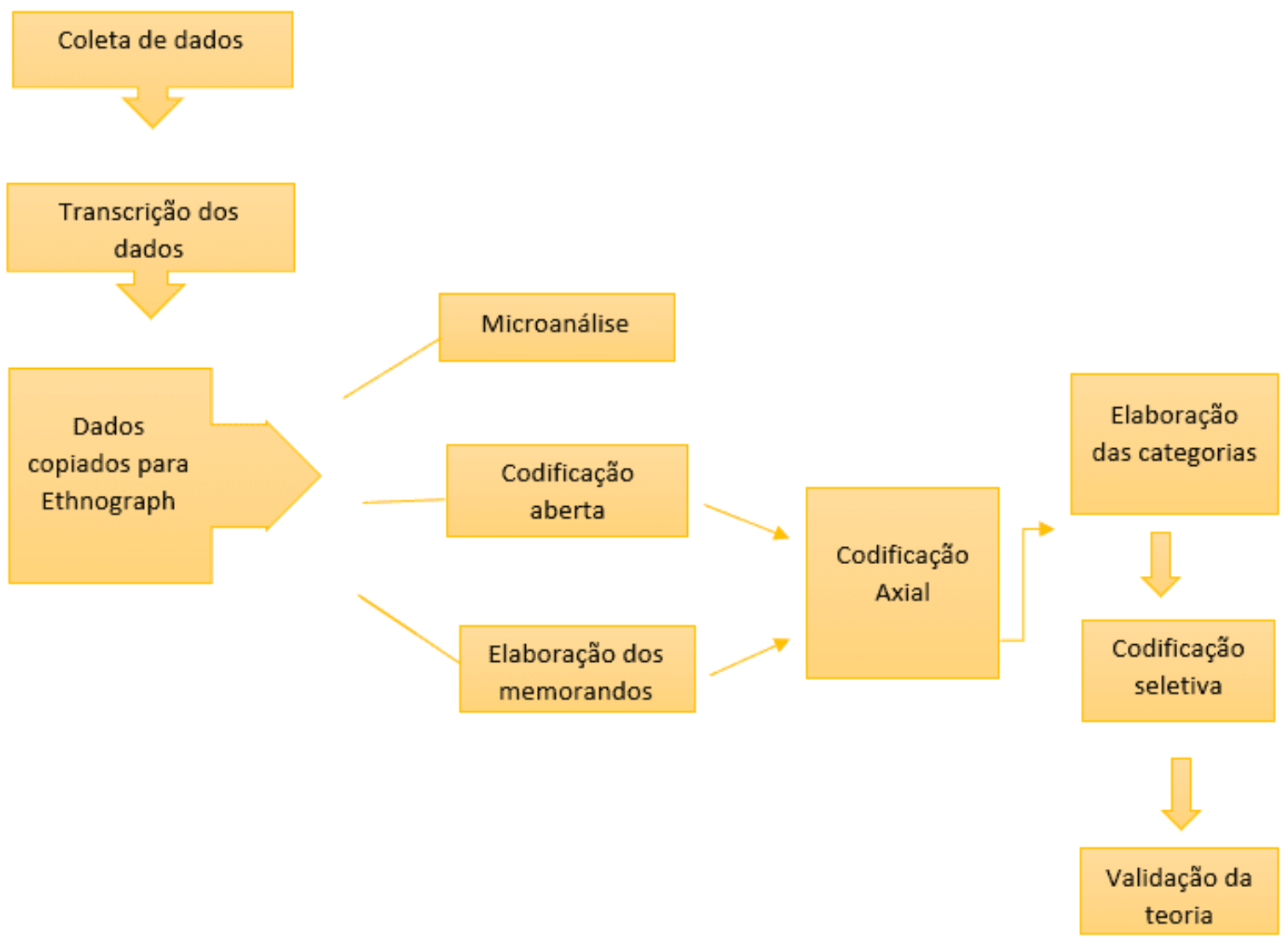

Fonte: Elaborado pela pesquisadora. 


\section{RESULTADOS E DISCUSSÃO}

Os resultados apresentados nesse artigo, foram extraídos de uma pesquisa com os alunos do primeiro ano do ensino médio. Foram encontradas três categorias emergentes dos dados que conduzem a compreensão do significado de sucesso profissional para o jovem, por meio de crenças, valores e influências socioculturais. A emersão destas categorias conduziu a discussão aqui sintetizada.

Por meio da análise dos dados, foram obtidas as seguintes categorias: Variáveis na forma de conceber o sucesso profissional, Condições que viabilizam ou não obter sucesso profissional e Elaboração estratégica para obtenção do sucesso profissional.

Conforme a tabela 1, os dados coadunam na categoria: Variáveis na forma de conceber o sucesso profissional.

\begin{tabular}{|l|l|l|l|}
\hline Tabela 01 - Sucesso profissional: e suas variáveis \\
\hline Categorias & $\begin{array}{l}\text { Subcategoria } \\
\text { Viabilização } \\
\text { do sucesso } \\
\text { profissional } \\
\text { por meio da } \\
\text { realização } \\
\text { pessoal }\end{array}$ & Autorrealização & $\begin{array}{l}\text { Fragmentos das } \\
\text { Entrevistas }\end{array}$ \\
\hline & $\begin{array}{l}\text { Aluno Eletr. B: "Eu } \\
\text { penso que sucesso } \\
\text { profissional é você se } \\
\text { dá bem na sua carreira, } \\
\text { na sua profissão. Você } \\
\text { fica feliz dentro do que } \\
\text { a pessoa gosta de } \\
\text { fazer, trabalha naquilo } \\
\text { que gosta". }\end{array}$ \\
\hline & & $\begin{array}{l}\text { "[...]eu acho que a } \\
\text { pessoa tem que fazer o } \\
\text { que ela gosta e seguir a } \\
\text { profissão que ela gosta, }\end{array}$ \\
& &
\end{tabular}




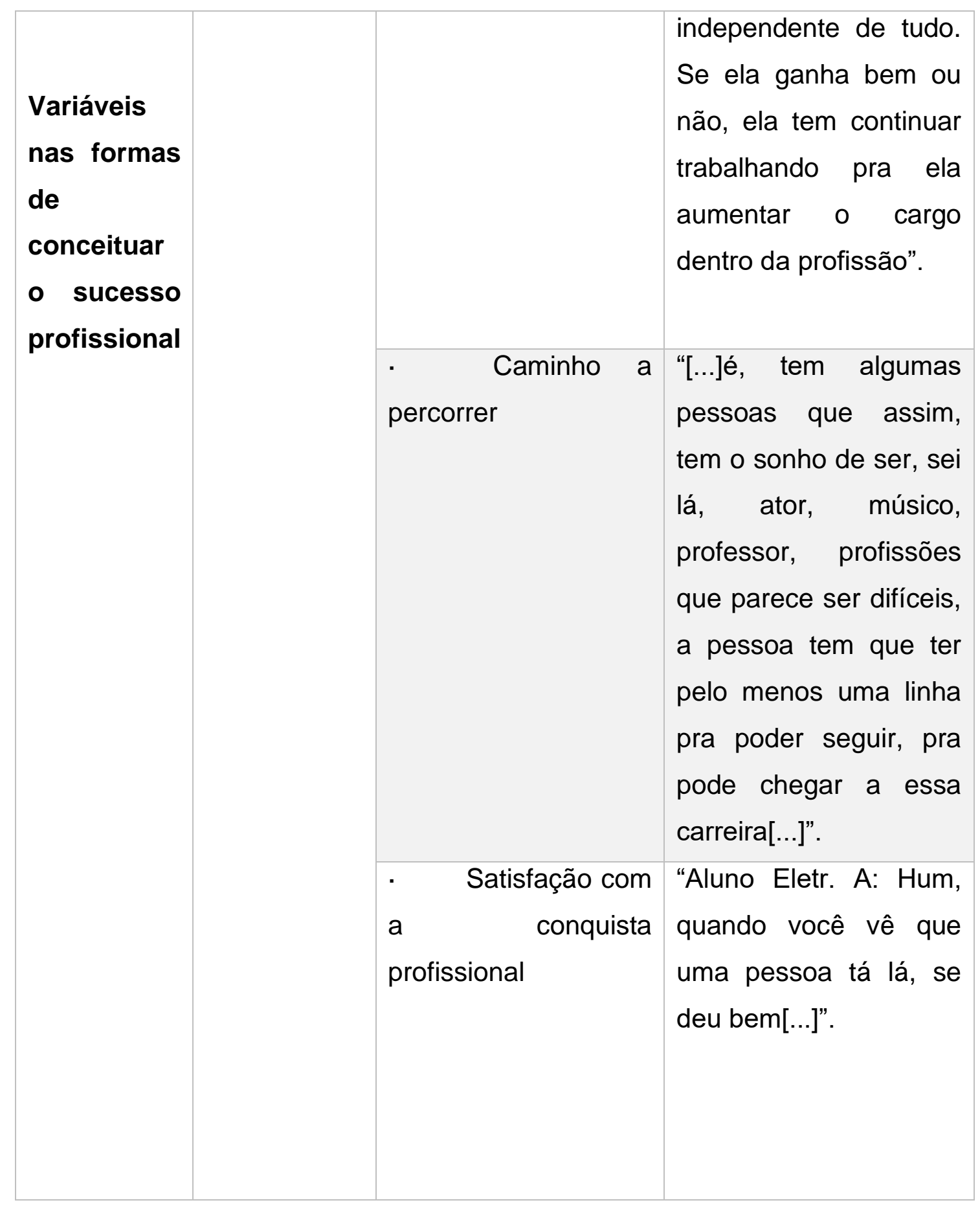




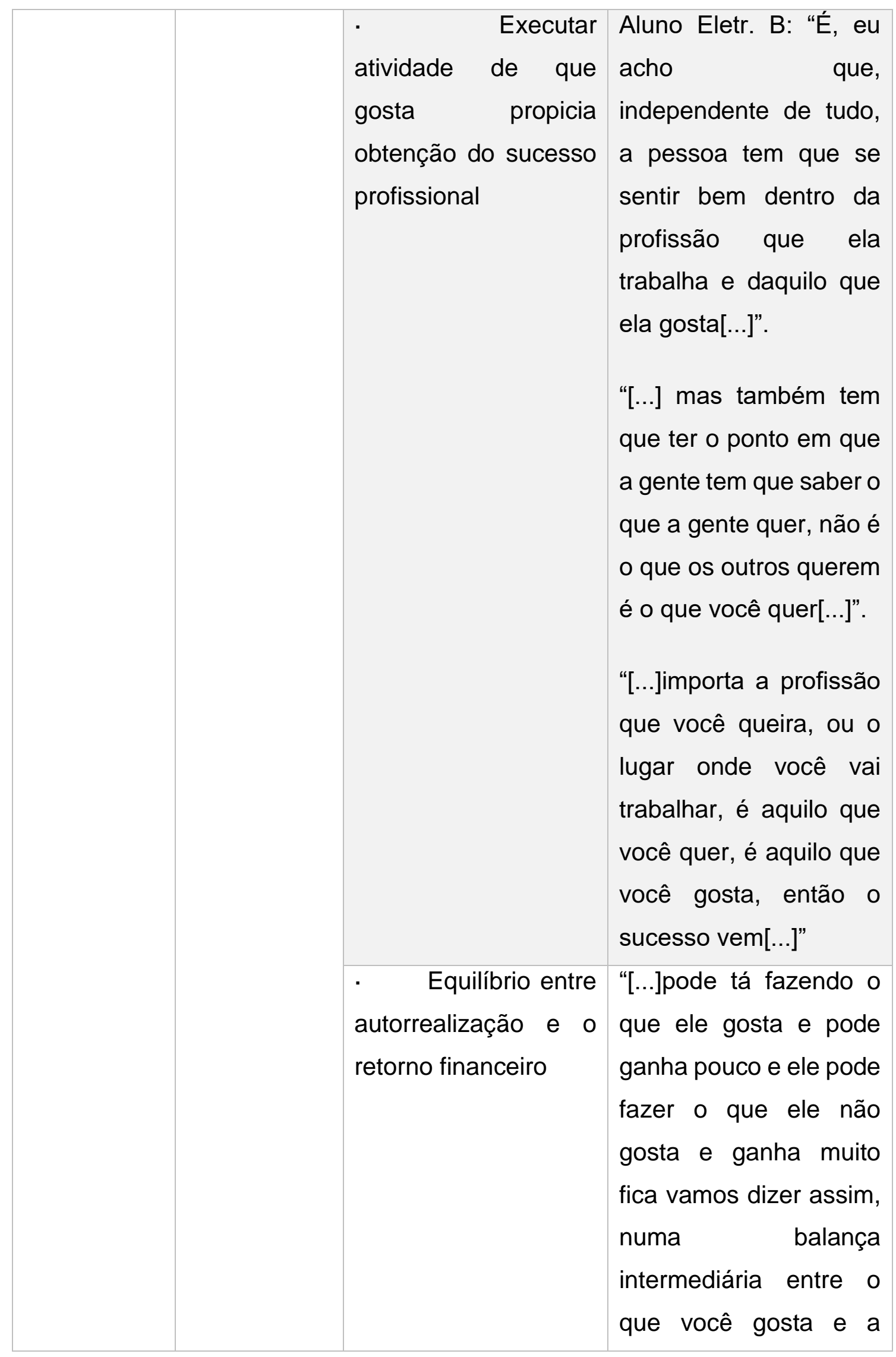




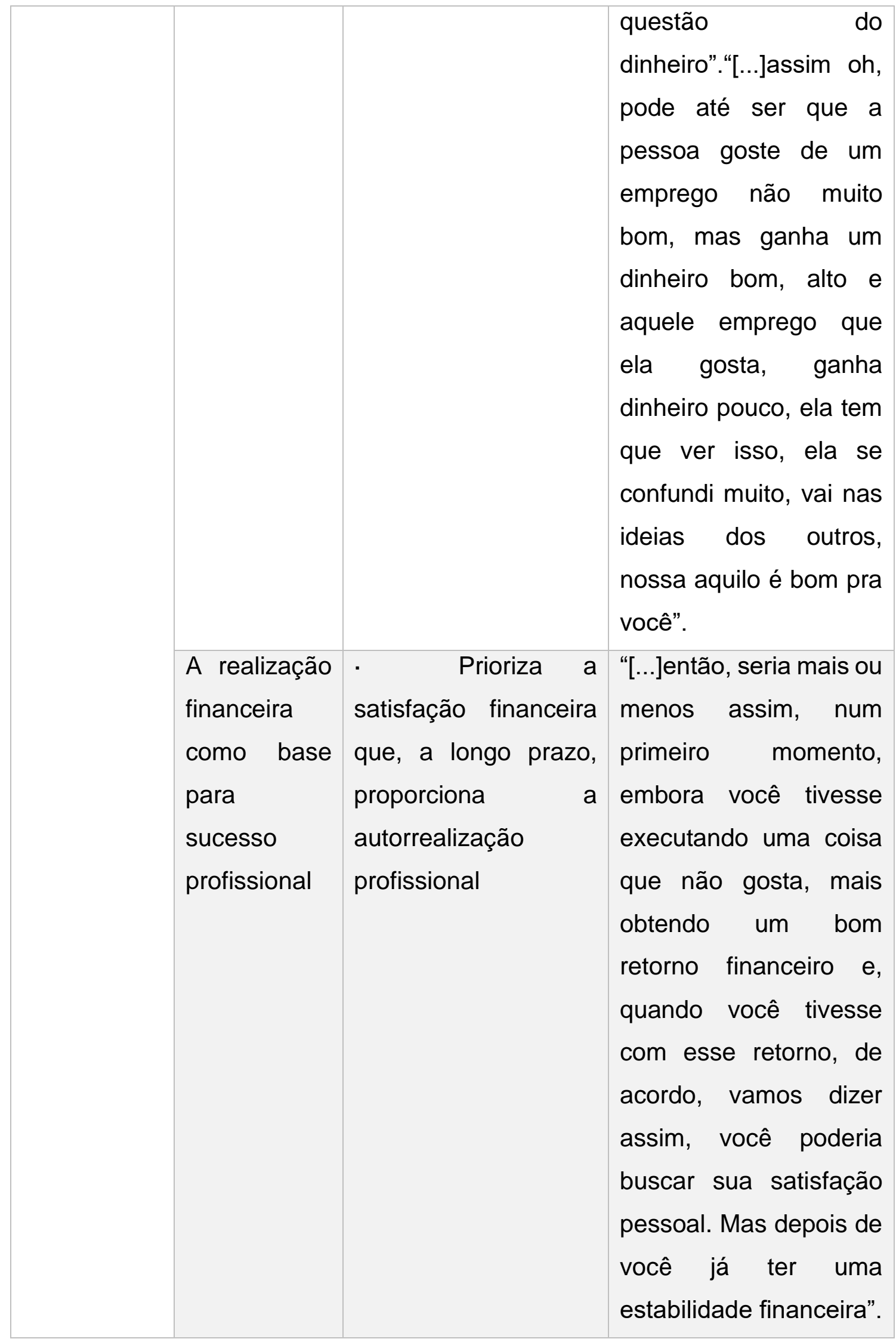




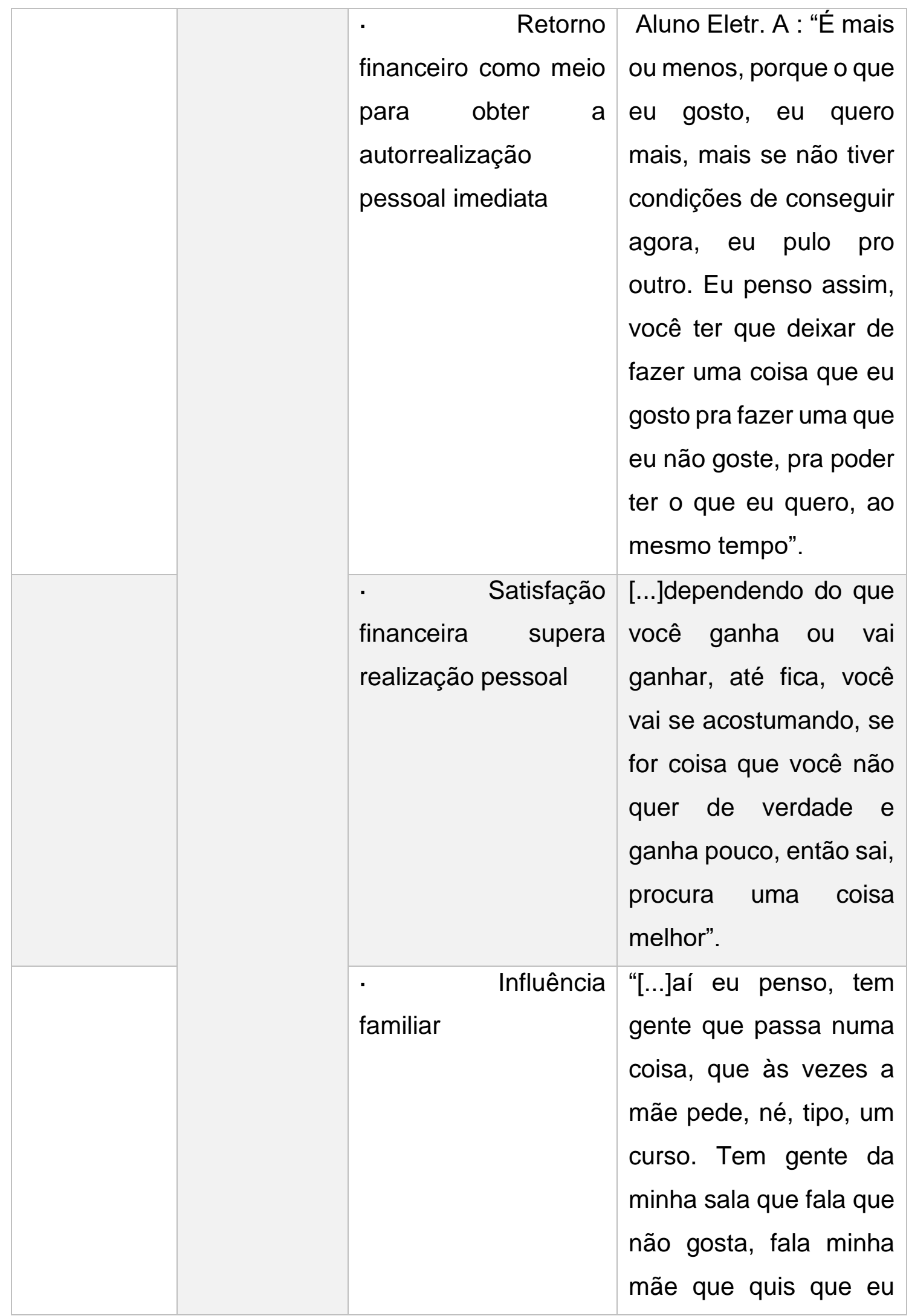




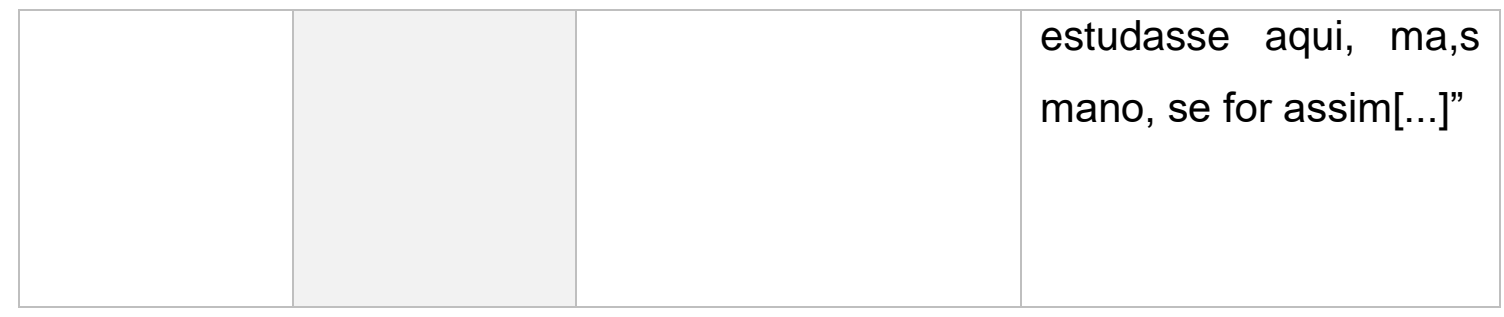

Fonte: Elaborada pela pesquisadora

Nos estudos aqui realizados, a definição de sucesso consiste em uma variedade de conceituações, como aponta Maia (2000). Conforme essa consideração, na análise, a realização pessoal é percebida pelos entrevistados como uma das formas na obtenção do sucesso profissional, quando o jovem faz o que gosta.

Essa percepção dos sujeitos de pesquisa coaduna-se com o que defendem VenelliCosta et al. (2017), sobre o sucesso profissional ser compreendido por meio de autorrealização pessoal, sobrepondo valores como a obtenção de dinheiro, posição na sociedade ou títulos.

De forma antônima, os mesmos resultados também identificam que o sucesso profissional se vincula ao fator financeiro, como forma de obtê-lo. A existência de ampla variação na definição do termo, ocasionando possíveis associações como a riqueza, status social e a realizações positivas imprimem ao conceito um significado subjetivo (Oliveira et al, 2013).

A tabela 2 formulada retrata as Condições que viabilizam ou não obter sucesso profissional.

Tabela 02 - Condições para o sucesso

\begin{tabular}{|l|l|l|l|}
\hline Categoria & Subcategoria & Códigos & $\begin{array}{l}\text { Fragmentos das } \\
\text { Entrevistas }\end{array}$ \\
& & & \\
& & Dificuldade \\
em desenvolver- & Aluno Eletr. B:" Você não \\
se no trabalho & que experiência naquilo \\
& & quecê tá \\
\hline
\end{tabular}




\begin{tabular}{|c|c|c|c|}
\hline & $\begin{array}{l}\text { Refinamento } \\
\text { da conduta } \\
\text { como forma } \\
\text { de inserção } \\
\text { social }\end{array}$ & $\begin{array}{l}\text { por falta de } \\
\text { experiência }\end{array}$ & $\begin{array}{l}\text { fazendo[...]não tá } \\
\text { consciente daquilo que } \\
\text { você tá fazendo, é um } \\
\text { ponto negativo, não } \\
\text { saber lidar com as } \\
\text { pessoas direito, } \\
\text { trabalhar em grupo, não } \\
\text { ter paciência, ficar } \\
\text { nervoso". }\end{array}$ \\
\hline $\begin{array}{l}\text { Condições } \\
\text { que } \\
\text { viabilizam } \\
\text { ou não } \\
\text { obter } \\
\text { sucesso } \\
\text { profissional }\end{array}$ & & $\begin{array}{l}\text { Padrão de } \\
\text { comportamento } \\
\text { inadequado }\end{array}$ & $\begin{array}{l}\text { "[...]pode prejudicar ele } \\
\text { tanto na entrevista de } \\
\text { trabalho, como eles } \\
\text { falaram, palavras de } \\
\text { baixo calão, gíria, } \\
\text { comportamento } \\
\text { malcriado, que pode ter } \\
\text { vindo tanto da família } \\
\text { como da escol. Ah, o } \\
\text { coleguinha tá } \\
\text { experimentando droga, } \\
\text { ah, vou experimentar } \\
\text { também. Aí sua vida vira } \\
\text { de cabeça para baixo, } \\
\text { ele começa a entrar na } \\
\text { laia dos outros, pra } \\
\text { começar a se sentir } \\
\text { incluído. É o que todo } \\
\text { mundo fala, é a Maria vai } \\
\text { com as outras, se o } \\
\text { coleguinha tá lá, tá } \\
\text { fumando }\end{array}$ \\
\hline
\end{tabular}




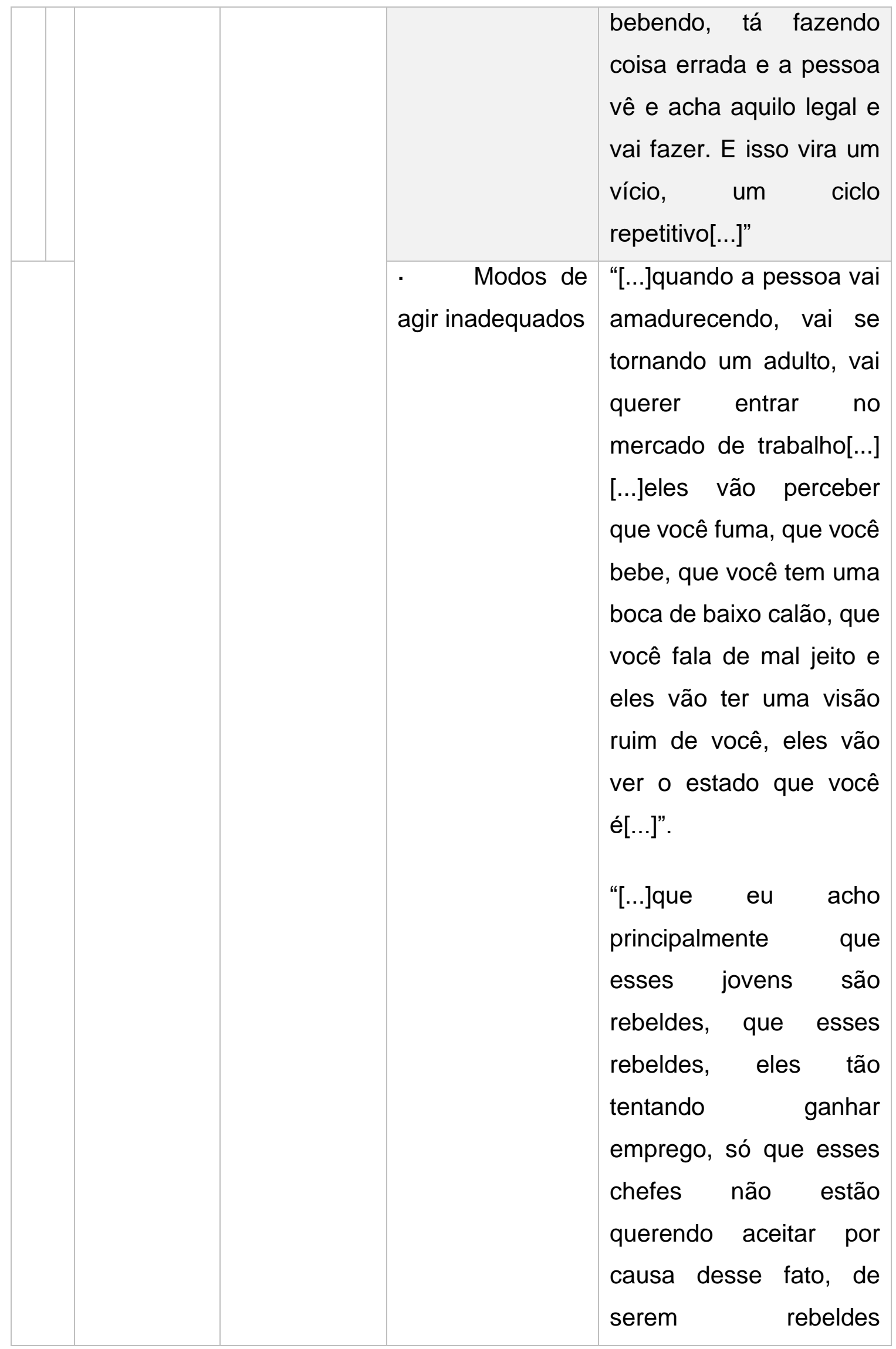




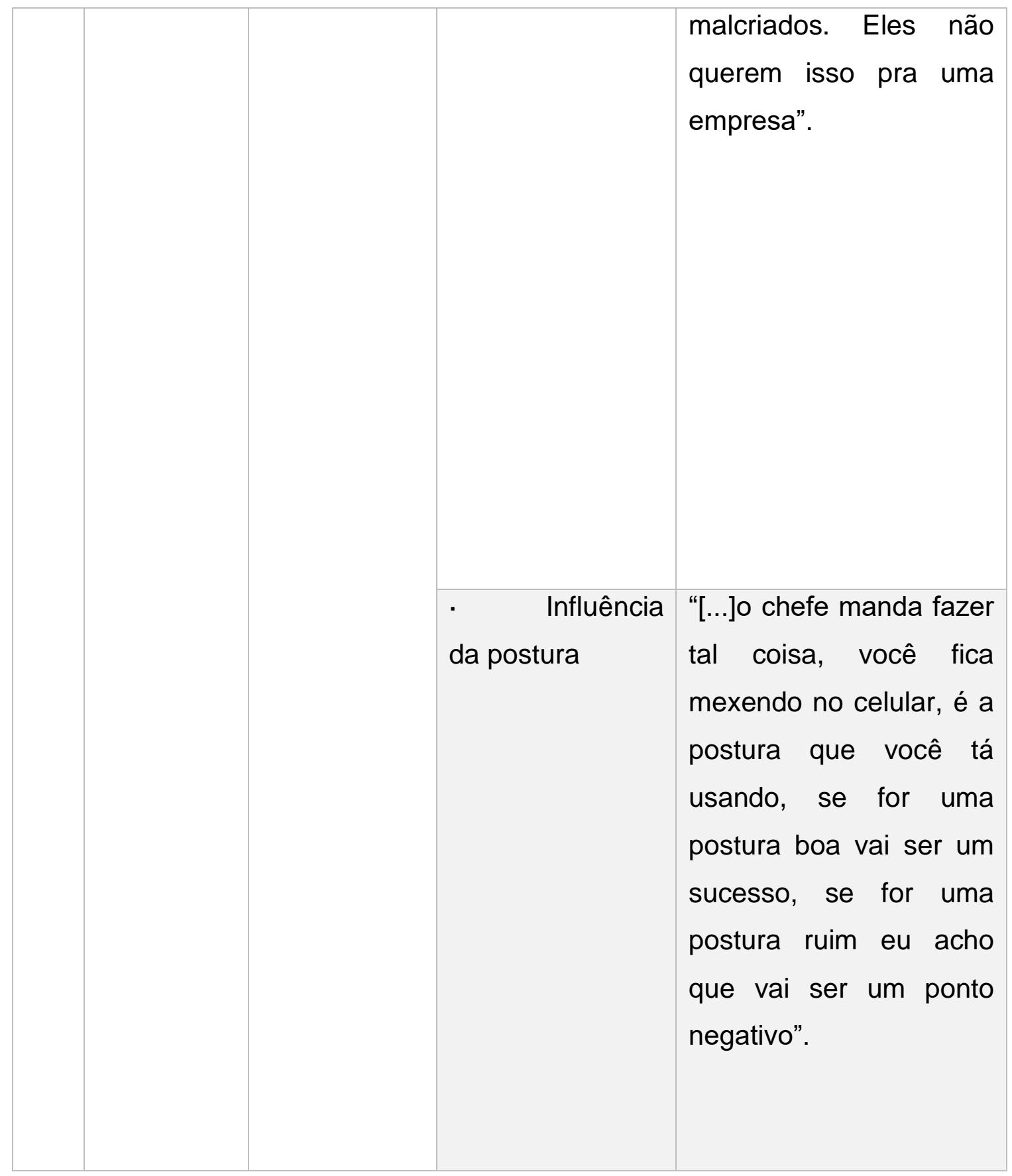




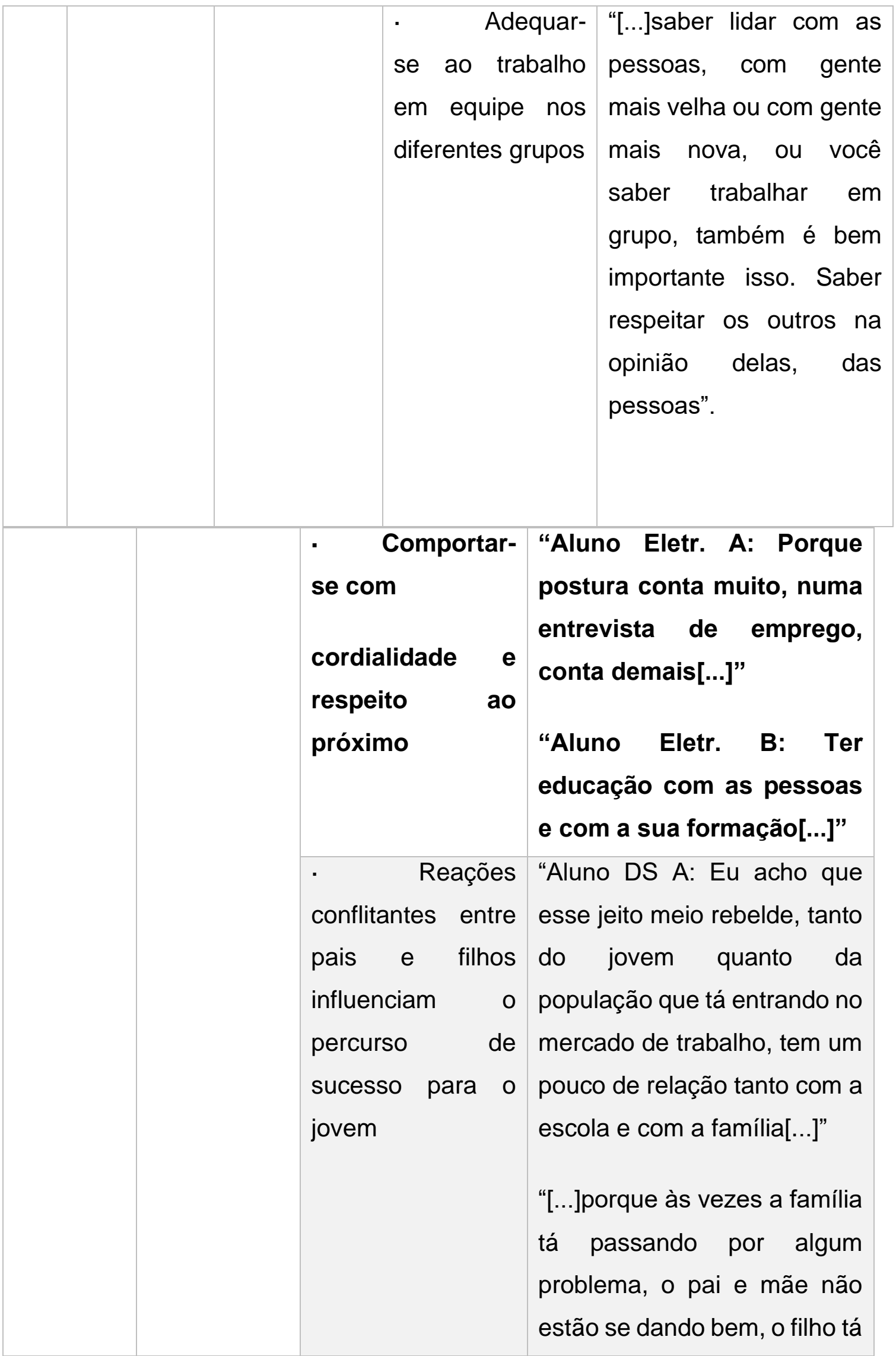




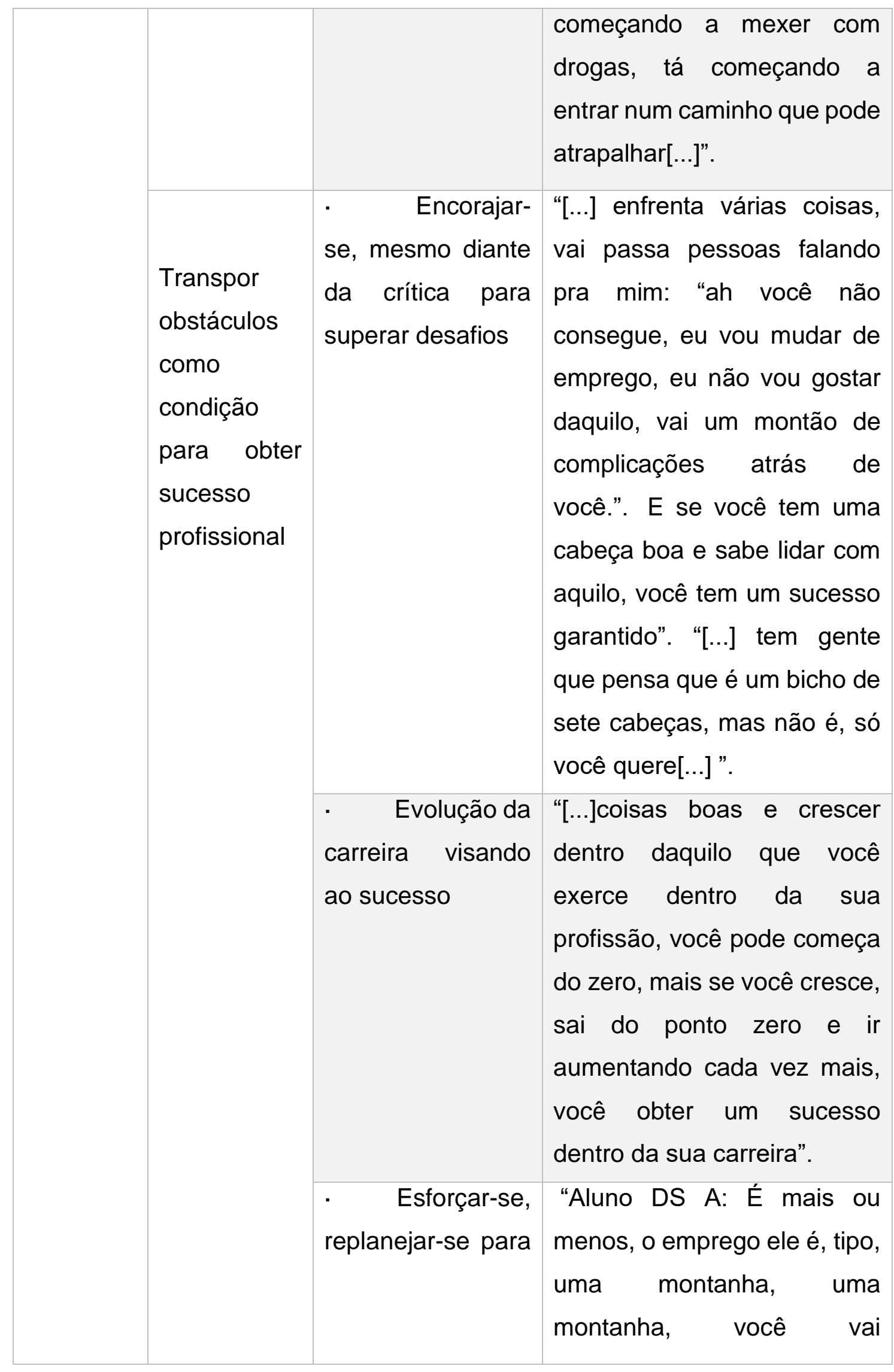




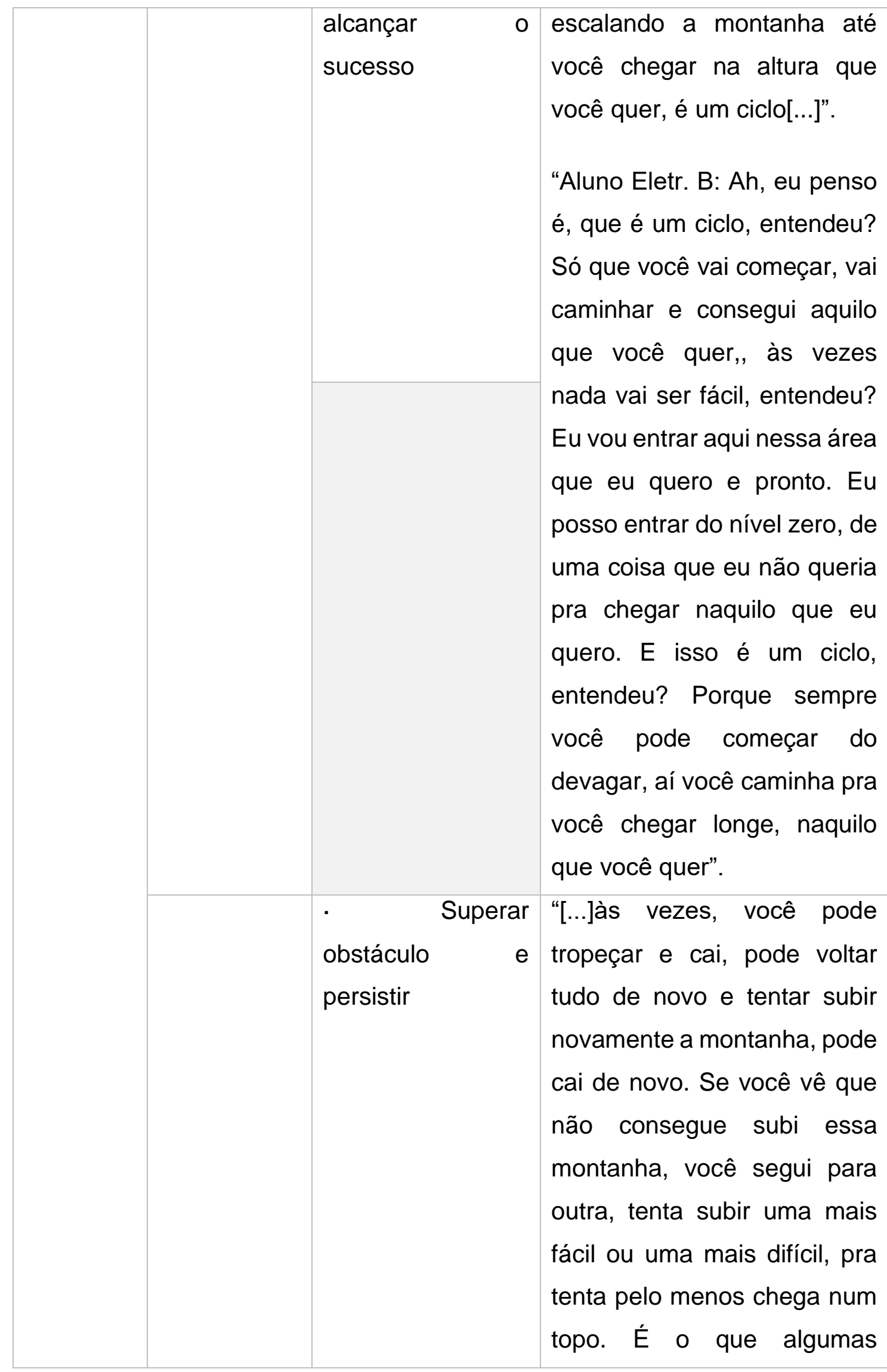




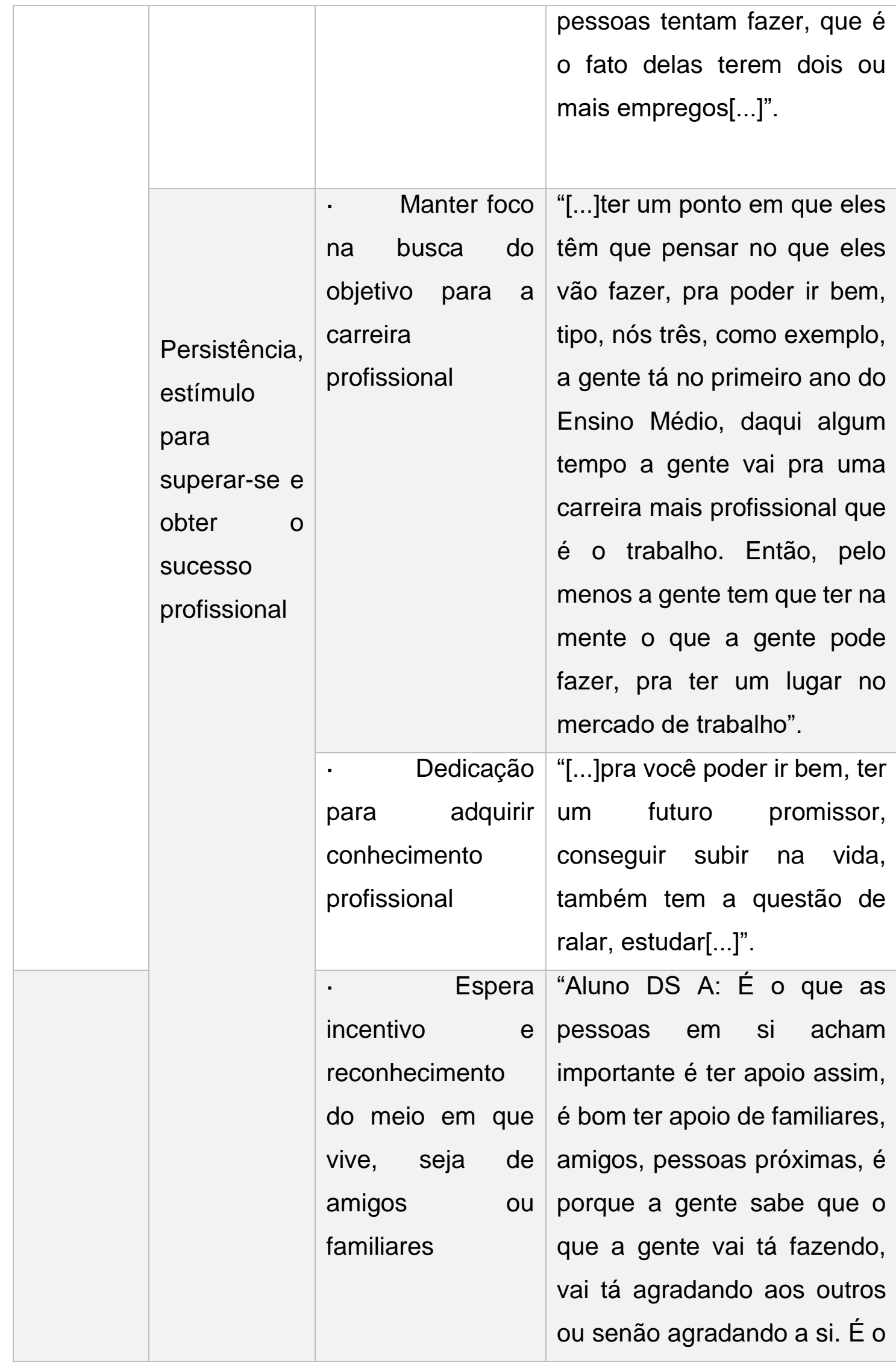




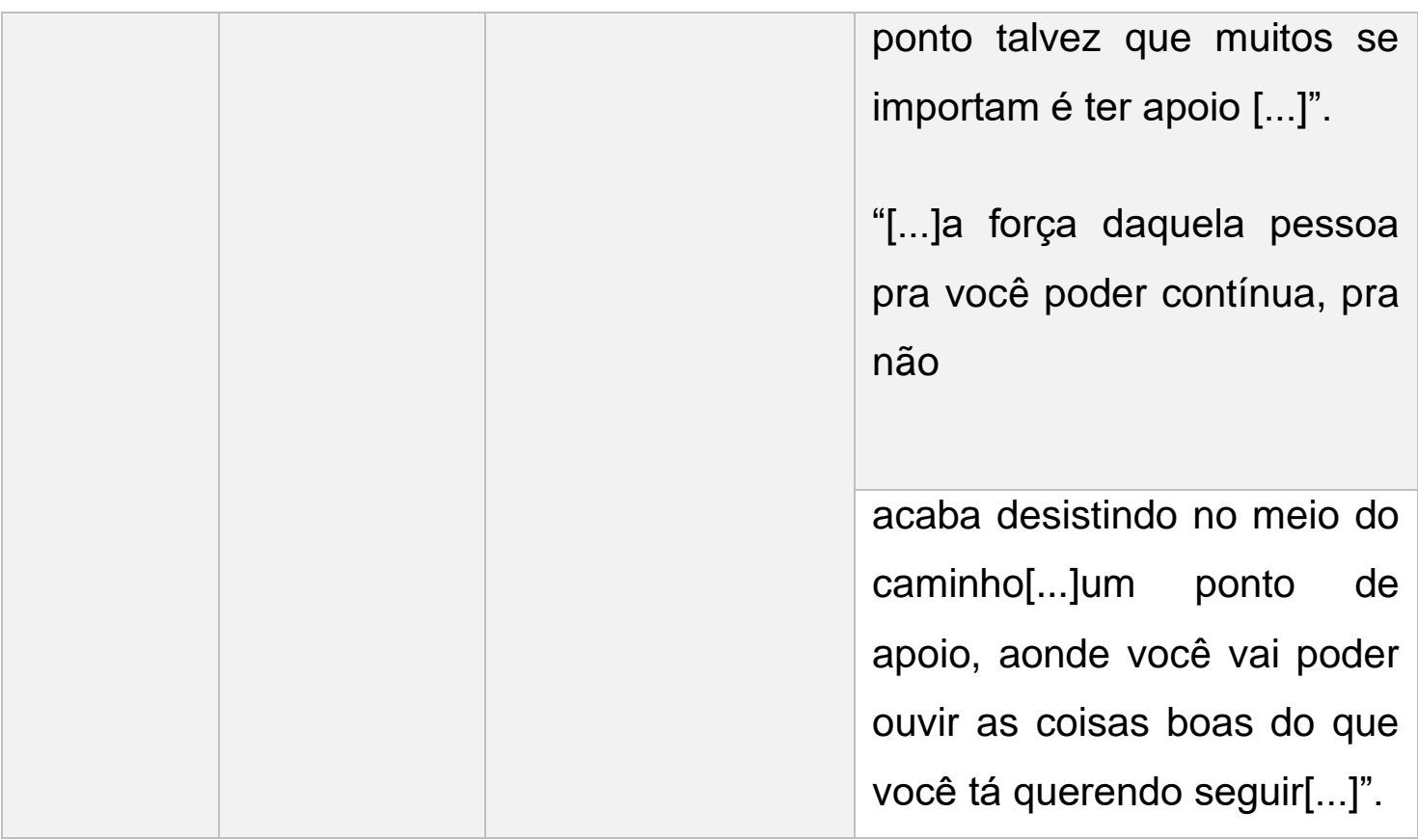

Fonte: Elaborada pela pesquisadora

$\mathrm{Na}$ observação dos dados, é possível observar o código comportamento inadequado do jovem como o uso de vocabulário pobre e ora rebelde, em uma etapa na qual ocorre transformação psicossocial na vida jovem (Junqueira, 2010). Essa postura inadequada exerce influência negativa na busca pelo sucesso profissional, tornandose um fator condicionante na inserção no mercado de trabalho.

$\mathrm{Na}$ compilação dos códigos que remetem à origem da categoria Condições que viabilizam ou não obter sucesso profissional , foi possível observar que o jovem, na busca pelo sucesso profissional, pode encontrar obstáculos que vão desde recursos financeiros, sua condição social até a forma como o seu contexto the proporciona o acesso ao mundo do trabalho (Bastos, 2005).

Se o contexto social e os recursos financeiros são obstáculos para o jovem, por outra ótica, a sua perseverança reflete seu desejo em obter sucesso profissional. Nesse aspecto, o estímulo para superar-se e obter o sucesso profissional retrata que a dedicação, o incentivo do grupo de pertença e o objetivo almejado são fatores estimulantes na obtenção do sucesso. Essas ponderações conduzem à ideia de que a orientação profissional pode auxiliar o jovem nesse caminho a percorrer e na 
percepção do seu potencial, conduzindo-o a um curso ou profissão desejada (Santana, 2017).

Finalizando a análise dos dados, obteve-se a categoria Elaboração estratégica para obtenção do sucesso profissional, ilustrada na tabela 3.

\section{Tabela 03 - Estratégias para atingir o sucesso profissional}

\begin{tabular}{|c|c|c|c|}
\hline Categorias & Subcategorias & Códigos & $\begin{array}{l}\text { Fragmentos das } \\
\text { Entrevistas }\end{array}$ \\
\hline $\begin{array}{l}\text { Elaboração } \\
\text { estratégica }\end{array}$ & $\begin{array}{l}\text { Planejamento } \\
\text { e ação para } \\
\text { alcançar } \\
\text { conquistas }\end{array}$ & $\begin{array}{l}\text { Planejamento } \\
\text { para alcançar } \\
\text { sucesso }\end{array}$ & $\begin{array}{l}\text { "[...]então, eu penso e } \\
\text { acho que a pessoa tem } \\
\text { que ter uma linha pra } \\
\text { saber o que ela quer, } \\
\text { como conseguir, o que } \\
\text { fazer pra conseguir e } \\
\text { chegar a esse ponto que } \\
\text { é o emprego dos sonhos } \\
\text { dela. } \\
\text { Aluno Eletr. A: É tipo } \\
\text { uma redação, né, } \\
\text { começo, meio e fim". }\end{array}$ \\
\hline $\begin{array}{l}\text { para } \\
\text { obtenção do } \\
\text { sucesso } \\
\text { profissional. }\end{array}$ & & $\begin{array}{l}\text { Estabelecer } \\
\text { meta para chegar } \\
\text { ao sucesso }\end{array}$ & $\begin{array}{l}\text { Aluno Eletr. A: "Estudar } \\
\text { bem, muito, tentar } \\
\text { entender, se não } \\
\text { entendeu, pergunta pro } \\
\text { professor, suga ele o } \\
\text { máximo possível[...]". } \\
\text { "[...] pega o que você tem } \\
\text { que fazer e segui em } \\
\text { frente, aí no final de tudo }\end{array}$ \\
\hline
\end{tabular}




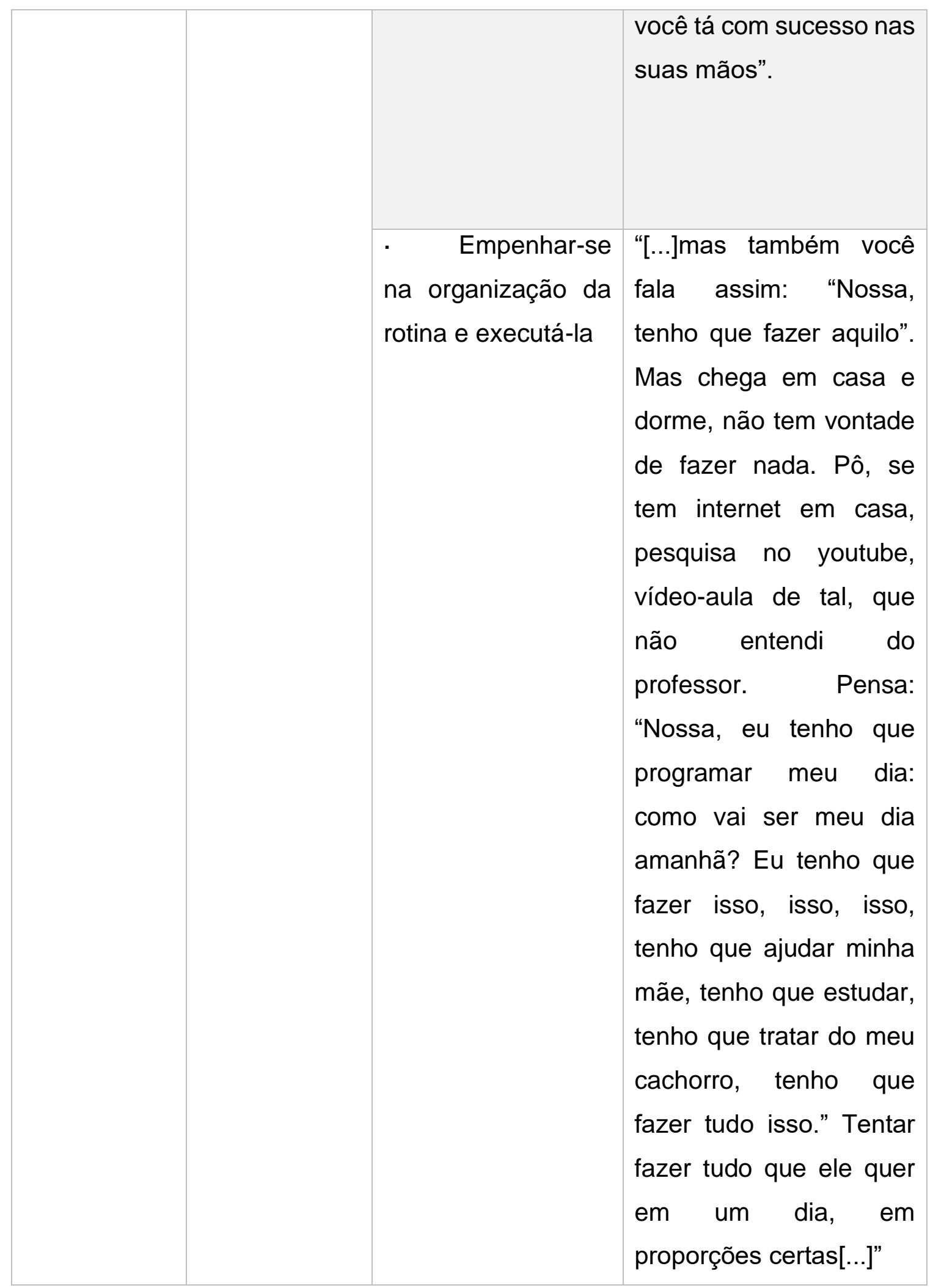




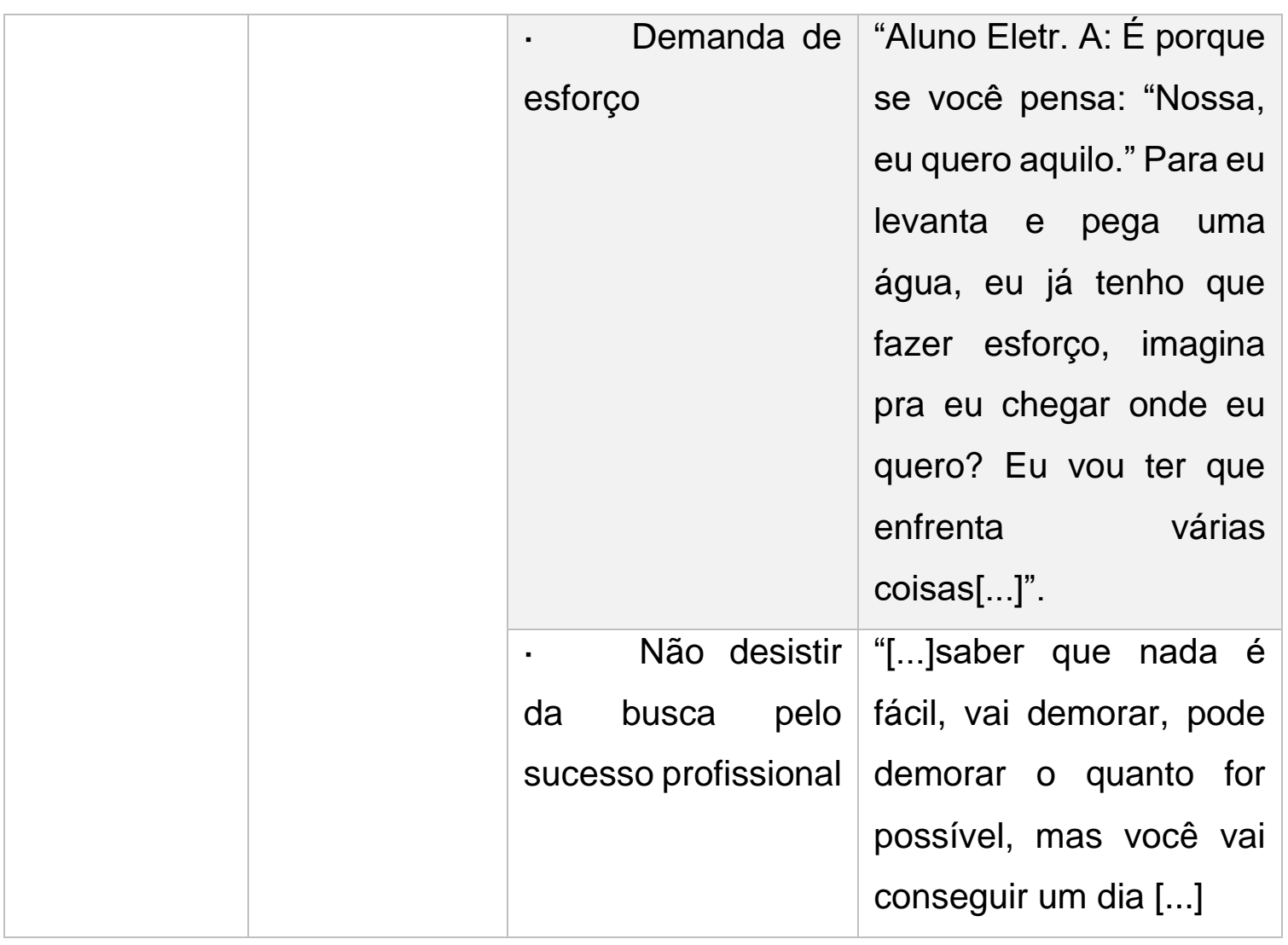

Fonte: Elaborada pela pesquisadora

No momento da escolha por uma carreira, o jovem confronta-se com aspectos voltados a sua condição socioeconômica e cultural, as quais podem interferir em suas opções (Santana, 2017). Baseado nessa consideração, observou-se que a manutenção de um planejamento, como estratégia de sucesso profissional, é fato evidenciado nos resultados, por meio dos códigos obtidos nas narrativas dos sujeitos desse estudo.

Além do planejamento, a opção pela carreira é outro fator que evidencia o amadurecimento do jovem, já que sua escolha profissional deve ser promotora de satisfação pessoal (Junqueira, 2010).

A percepção de sucesso, que as categorias emergentes dos dados propiciam em nossa pesquisa, é o fomento da singularidade da imersão do fenômeno, o qual leva em consideração fatores socioeconômicos e culturais da vida dos jovens, como promotores ou não de sucesso profissional. Visto por essa ótica, o conceito de 
sucesso assume o viés da subjetividade, que se vem discutindo ao longo desse estudo.

Para melhor compreensão desse fenômeno, a Figura 2 ilustra o fenômeno central da pesquisa, Singularidade dos fatores socioeconômicos e culturais, mediante a subjetividade do conceito de sucesso profissional, considerando os resultados obtidos com os alunos do primeiro ano do Ensino Médio, por meio das categorias emergentes.

Figura 2 - Fenômeno central da pesquisa

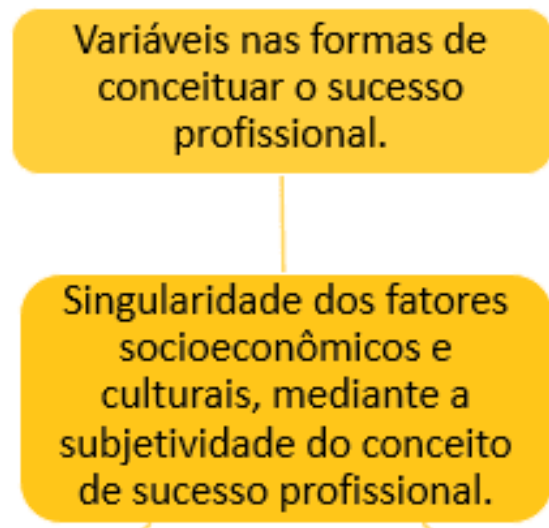

Elaboração estratégica para obtenção do sucesso profissional.
Condições ou não que viabilizam ou não obter sucesso profissional

Fonte: Elaborado pela pesquisadora.

\section{CONSIDERAÇÕES FINAIS}

Esta pesquisa objetivou compreender o significado de escolha profissional para o jovem do ensino médio, por meio da influência do seu contexto socioeconômico e familiar, identificando suas crenças e valores.

Os resultados foram obtidos por meio de um grupo focal realizado com três alunos do primeiro ano do ensino médio, o que caracteriza uma limitação de considerações 
emergentes dos dados devido a pequena amostra. Neste contexto foi possível identificar que os alunos do primeiro ano do ensino médio, denotam que o sucesso profissional está vinculado as suas condições socioeconômicas e seus proventos, que algumas vezes são dificultadores, porém não limitadores para que continuem a buscar o sucesso almejado. Recorrem a orientação profissional por exemplo, como forma de expandir possibilidades e desta forma alcançar o sucesso profissional. Por meio das considerações dos jovens, e da estratégia adotada, voltada à obtenção de recursos financeiros, realização profissional, status ou cargo alcançado, revelam a singularidade e subjetividade que o jovem do ensino médio na contemporaneidade, significa o sucesso profissional.

Visando contribuir em futuras pesquisas de interesse pelo tema, esta abordagem pode ter outro desdobramento, se considerarmos a ideia de investigar como o jovem do ensino médio de escola particular compreende o significado de sucesso profissional, fomentando a discussão pelo tema e contribuindo com novas investigações sob uma nova ótica do aluno de escola privada.

\section{REFERÊNCIAS}

BASTOS, Juliana Curzi Efetivação de Escolhas Profissionais de Jovens Oriundos do Ensino Público: Um Olhar sobre suas Trajetórias. Revista Brasileira de Orientação Profissional v.6, n.2, p.31- 43, 2005. Disponível em http://pepsic.bvsalud.org/pdf/rbop/v6n2/v6n2a04.pdf Acesso em: 01 mai. 2018.

BONFIM, Leny A Grupos Focais: conceitos, procedimentos e reflexões baseadas em experiências com o uso da técnica em pesquisas de saúde. Physis. Revista de Saúde Coletiva, Rio de Janeiro, v.19, n.3, p.777-796, 2009. Disponível em http://www.scielo.br/pdf/physis/v19n3/a13v19n3.pdf Acesso em: 11 ago. 2018.

BUSCACIO, Reiviani Chiste Zanotelli; SOARES, Adriana. Benevides. Expectativas de Carreira em Universitários. Revista Brasileira de Orientação Profissional, v.8, n.1, p.69-79, 2017. Disponível em http://pepsic.bvsalud.org/pdf/rbop/v18n1/07.pdf Acesso em: 13 mai. 2018. 
JUNQUEIRA, Maria Luiza; Maturidade para a escolha da carreira em adolescentes de um serviço de orientação profissional. Dissertação (Mestrado em Psicologia)

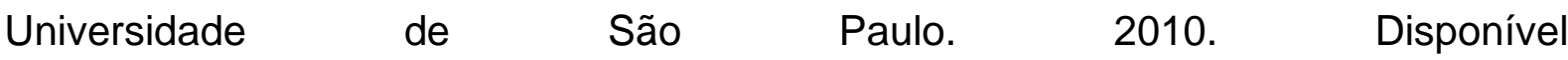
em http://www.teses.usp.br/teses/disponiveis/59/59137/tde-29032011-210529/ptbr.php Acesso em: 21 jun. 2018.

MAIA, Nuno Álvaro Vidal As Representações sociais de sucesso: Efeito do meio profissional e do sexo de pertença na representação do sucesso profissional. Dissertação (Mestrado de Psicologia) Faculdade de Psicologia e de Ciências da Educação da Universidade do Porto. Porto, 2000. Disponível em https://repositorioaberto.up.pt/bitstream/10216/23396/2/29889.pdf. Acesso em: 13 de mai. 2018.

MAIA, Nuno; POESCHL Gabrielle Efeito do meio profissional nas representações do sucesso profissional. PSICOLOGIA, Vol. X V III, n.1, p. 47- 65,2004. Disponível em http://www.scielo.mec.pt/pdf/psi/v18n1/v18n1a04.pdf. Acesso em: 01 mai. 2018.

MINAYO, Maria Cecília Souza (ORG.). Pesquisa Social. Teoria, método e criatividade. 21 ed. Petrópolis: Vozes, 2002.

NORONHA, Ana Paula Porto; OTTATI, Fernanda Interesses profissionais de jovens e escolaridade dos pais. Revista Brasileira de Orientação Profissional v.11, n.1, p.37-47, jan/jun. $2010 . \quad$ Disponível em: http://pepsic.bvsalud.org/pdf/rbop/v11n1/v11n1a05.pdf. Acesso em: 02 mai. 2018.

OLIVEIRA, Marina Cardoso; DETOMINI, Vitor Côrrea; SILVA, Lucy Leal Melo. Sucesso na transição universidade-trabalho: expectativas de universitários formandos. Psicologia em Revista, Belo Horizonte, v. 19, n. 3, p. 497-518, dez. 2013. Disponível em: http://pepsic.bvsalud.org/pdf/per/v19n3/v19n3a11.pdf. Acesso em: 20 jul. 2018

SANTANA, M Leonor. Representações sociais da escolha profissional pelos alunos do ensino médio do campo/cidade. Dissertação (Mestrado em Desenvolvimento Humano) Universidade de Taubaté. Taubaté. São Paulo 2017. Disponível 
http://mpemdh.unitau.br/wpcontent/uploads/2015/dissertacoes/mdh/LeonorMSantana pdf. Acesso em: 22 abr. 2018.

SOUZA, Luiz Gustavo Silva et al. Sentidos atribuídos ao sucesso pessoal e profissional em estudantes do ensino médio. Revista de Psicologia da Vetor. Vitória, v. $8, \quad$ n.1, p.1-12, jan./jun. 2007. Disponível em: http://pepsic.bvsalud.org/pdf/psic/v8n1/v8n1a02.pdf. Acesso em: 21 ago. 2018.

STRAUSS, Anselm; CORBIN, Juliet. Pesquisa qualitativa: técnicas e procedimentos para o desenvolvimento de teoria fundamentada; tradução Luciane de Oliveira da Rocha. 2.ed.; Porto Alegre: Artmed, 2008, 288p.

VENELLI-COSTA, Luciano; RODRIGUES, Carolina Laender Moura Munõz.; KILIMNIK, Zélia Miranda; MESQUITA, José Marcos Carvalho Fatores de Qualidade de Vida no Trabalho e Sucesso na Carreira: Um Estudo com Médicos da Cidade de Belo Horizonte. Revista de Administração Hospitalar e Inovação em Saúde, v. 14, n. 3, p. 34-52, 2017. Disponível em: www.spell.org.br/documentos/ver/49343/ Acesso em: 29 jul. 2018.

Enviado: Março, 2020.

Aprovado: Abril, 2020. 